\title{
IODINE-129: A REVIEW OF ITS POTENTIAL IMPACT ON THE ENVIRONMENT
}

\author{
$80^{0^{\circ}}$ John W. Poston, Ph.D \\ 216. School of Nuclear Engineering \\ Georgia Institute of Technology \\ Atlanta, Georgia 30332
}

May, 1978

\section{MASTER}

This report was prepared by John W. Poston under Consultant Subcontract 7278 with Union Carbide Corporation, Nuclear Division. The subcontract was administered by the office of Waste Isolation.

\section{OFFICE OF WASTE ISOLATION} OAK RIDGE. TENNESSEE

prepared for the U.S. DEPARTMENT OF ENERGY under

U.S. GOVERNMENT Contract W-7405 eng 26

The assumptions, views, and conclusions expressed in this document are those of the author and are not to be interpreled as those of Union Carbide Corporation, Nuclear Division, or the Department of Energy. 


\section{DISCLAIMER}

This report was prepared as an account of work sponsored by an agency of the United States Government. Neither the United States Government nor any agency Thereof, nor any of their employees, makes any warranty, express or implied, or assumes any legal liability or responsibility for the accuracy, completeness, or usefulness of any information, apparatus, product, or process disclosed, or represents that its use would not infringe privately owned rights. Reference herein to any specific commercial product, process, or service by trade name, trademark, manufacturer, or otherwise does not necessarily constitute or imply its endorsement, recommendation, or favoring by the United States Government or any agency thereof. The views and opinions of authors expressed herein do not necessarily state or reflect those of the United States Government or any agency thereof. 


\section{DISCLAIMER}

Portions of this document may be illegible in electronic image products. Images are produced from the best available original document. 
This report was prepared as an account of work sponsored by the United States Government. Neither the United States nor the Energy Research and Development Administration, nor any of their employees, nor any of their contractors, subcontractors, or their employees, makes any warranty, express or implied, or assumes any legal liability or responsibility for the accuracy, completeness or usefuliess of any infurmatiun, apparatus, product or process disclosed, or represents that its use would not infringe privately owned rights. 
This report was prepared as an account of work Uovernment. Neither the United States nor the United States Department of Energy, nor any of their employees, nor any of their contractors, subcontractors, or their employees, makes any warranty, express or implied, or assumes any legal liability or responsibuity for the accuracy, completeness or use fulness of any information, apparatus, product or process disclosed, or represents that its use would not

Iodine-129: A Review of its Potential Impact

on The Environment

John W. Poston, Ph.D

School of Nuclear Engineering

Georgia Institute of Technology

Atlanta, Georgia 30332

. May, 1978 
List of Figures. $\quad$ Page List of Tables.................. iv Abstract ..................... . . v v Introduction . . . . . . . . . . . . . . . . 1

Projections of ${ }^{129}$ I Production and Release . . . . . . 2 Summary of Metabolic and Physiologic Data. . . . . . . 5 Evaluations of ${ }^{129} \mathrm{I}$ Hazards. . . . . . . . . . 13 Summary and Conclusions. . . . . . . . . . . 34 Acknowledgements ................ . . . 37 References . . . . . . . . . . . . . . 38 


\section{List of Figures}

Figure 1: Schematic Diagram of Riggs' Model for Iodine Metabolism

Figure 2: Variation of Biological Half-Life of Iodine as a Function of Age

Figure 3: Weight of the Thyroid as a Function of Age

Figure 4: Age-Dependent Ingestion Dose Factor, $g_{\text {ingest }}$ 
Table.I. Estimated Ecological Parameters for Iodine

Table II. Aquatic Bioaccumulation Factors for Iodine

Table III: Parameters Used in Calculating Thyroid Dose Factors for ${ }^{129} \mathrm{I}$

Table IV. Thyroid Dose Factors for ${ }^{129} \mathrm{I}$

Table V. Thyroid Doses from Unit Concentration of ${ }^{129}$ I in Air

Table VI. Thyroid Doses from Unit Concentration of ${ }^{129} \mathrm{I}$ in Air

Table VII. Average Dietary Intake of Major Food Items by Representative Age Groups

Table VIII. Daily ${ }^{129}$ I Intake, Thyroid Burden, and Radiation Dose Rate Thyroids of 1-, 4-, and 14-year-olds, and Adults from Ingestion of Foods Produced at Locations with ${ }^{129}$ I Concentrations Equal to $1 \mathrm{pCi} / \mathrm{m}^{3}$ Air

Table IX. Parameters of the Geologic Formations

Table X. Step Function Response for ${ }^{129} \mathrm{I}$ in Several Geologic Formations.

Table XI. Concentration of Iodine-129 in the Water Reaching the Human Environment Expressed as Ratios to the Maximum Permissible Concentrations in Drinking Water

Table XII. Dose Equivalent per Unit Intake of 129 - Reference Man 


\section{Abstract}

Attention has been drawn to ${ }^{129} \mathrm{I}$, a radionuclide with a long halflife and the potential for long-term accumulation in the environment as a result of low-level, chronic releases from nuclear facilities such as nuclear fuel reprocessing plants. The metabolic and physiologic data on iodine, as well as the currently accepted metabolic models, are summarized. In addition, projections of iodine-129 production and release, as well as estimates of the potential hazards derived by various authors, are presented and discussed. The implications of these considerations on the deep geologic disposal of ${ }^{129} \mathrm{I}$ are reviewed and summarlzed. At this time there are limited data available to assess in detail the impact of releases of ${ }^{129} \mathrm{I}$ to the environment from a geologic waste repository. Since this isotope is essentially stable (has a low specific activity because of its long radioactive half-life) it has been generally regarded as not contributing significantly to the total population dose commitment. Therefore, the presence of this isotope in a waste repository should not significantly affect repository design and operation. However, additional research in several areas such as the movement of ${ }^{129} \mathrm{I}$ from a repository to the surface by ground water and the influence on uptake fraction of the incorporation of ${ }^{129} \mathrm{I}$ in foodstuffs would be useful to more accurately quantify envi.ronmental effects. 


\section{Int roduction}

The increased use of nuclear power generating facilities in the energy production strategy of many countries implies the increased production of many long-lived fission products which in the past were considered unimportant. The most notable of these is the isotope of iodine, ${ }^{129} \mathrm{I}$. Until recently this isotope of iodine was one of the least studied (Boulos et al, 1973, Gabay et al, 1973). Iodine-129 has a half-. life of about 17 million years and is produced with a fission yield of approximately $1 \%$ in the fission of ${ }^{235} \mathrm{U}$ (Gabay et al, 1973). During normal operation of a reactor, negligible amounts of iodine are released to the atmosphere at the reactor site. However, due to the long half-life of this radioisotope, it accumulates in the fuel during burnup. During subsequent chemical processing of spent fuel at a reprocessing plant, a much greater potential exists for discharge of a portion of the iodine-129 present in the fuel. Thus, it was suspected that ${ }^{129} \mathrm{I}$ may become a problem from the public health point of view at the fuel reprocessing stage of the fuel cycle (Magno et al, 1972).

It is estimated (Porz, 1974) that, in the fuel of an operating lightwater moderated reactor, ${ }^{13 l} I$ - activity is about $3 \times 10^{7}$. higher than the ${ }^{129} \mathrm{I}$ - activity. However, because ${ }^{131} \mathrm{I}$ has a half-life of only 8.04 days, after the spent fuel has been stored for 200 days, the ${ }^{13 l}$ I - activity drops to approximately the same value as the ${ }^{129} \mathrm{I}$ - activity. And, thereafter, the ${ }^{129} \mathrm{I}$ - activity represents the main portion of the iodine activity in the fuel (Hübschmann, 1975). It has been estimated that the average ${ }^{129}$ I throughput of a plant reprocessing one ton of fuel per day would be about $20 \mathrm{mCi} /$ day (Bryant, 1970). Bryant assumed the fuel was from a 
$10,000 \mathrm{MW}(\mathrm{e})$ power program averaging 1,000 days irradiation.

Any radioiodine discharged to the atmosphere and reaching man will accumulate in the thyroid gland. Critical pathways are either by ingestion via the pasture-cow-milk route or simply by inhalation. In the case of the short-lived iodine isotopes (e.g. ${ }^{131} \mathrm{I}$ ) the pathways are well documented and release limits have been established in many countries (see for example, Bryant, 1964; Baverstock and Vennart, 1976). However, similar considerations have only recently been afforded ${ }^{129} \mathrm{I}$. There remains a need for further work and study in this area, especially in resolving some of the conflicting conclusions reached by several authors. This manuscript collects and summarizes the existing data on ${ }^{129} \mathrm{I}$ and on iodine metabolism based on the extensive studies of ${ }^{131} \mathrm{I}$. The importance of ${ }^{129} \mathrm{I}$ in the evaluation of the impact of national waste repositories is considered in detail. It is hoped that by anticipating potential problems, an effective and timely response can be made to questions concerning the hazards evaluation of ${ }^{129} \mathrm{I}$.

\section{Projections of ${ }^{129} \mathrm{I}$ Production and Release}

The worldwide production of ${ }^{129}$ I by the year 2060 has been estimated to be $2 \times 10^{b} \mathrm{Ci}$ (Russell and Hahn, 1971). If a removal efficiency of $99 \%$ is assumed at the fuel reprocessing facility, there could be $2 \times 10^{4} \mathrm{Ci}$ of ${ }^{129} \mathrm{I}$ in the environment by 2060 . Originally, reprocessing facilities were not designed to remove iodine; hence, virtually all of the ${ }^{129}{ }^{I}$ would be released to the environment.

Russe11 and Hahn also estimated that, by the year 2060, the U.S. production of ${ }^{129} \mathrm{I}$ would be about $9 \times 10^{4} \mathrm{Ci}$. For comparison to other estimates, the data used by Russell and Hahn gives a value of approximately 3,000 Ci 
by the year 2000 . This estimate is not in complete agreement with that proposed by Blomeke and Kee (1974). These authors estimated an ${ }^{129} \mathrm{I}$ accumulation by the year 2000 of 7,400 $\mathrm{Ci}$. Neither manuscript gives sufficient information to resolve these discrepancies.

Morley and Bryant (1976) estimate the discharge rate of ${ }^{129} \mathrm{I}$ by: the year 2000 for the nuclear industry. throughout the world will be about $2 \times 10^{3} \mathrm{Ci} / \mathrm{yr}$. Blomeke and Kee (1976) gave revised estimates for the annual accumulation of radioiodine from the U.S. nuclear power industry. By the year 2000, the annual addition to the inventory will be about $370 \mathrm{Ci} / \mathrm{yr}$. with a total inventory of more than $3600 \mathrm{Ci}$ of ${ }^{129} \mathrm{I}$. This estimate is based on light water reactors (LWR) with 564 GWe installed capacity and liquid metal fast breeder reactors with a capacity of 61 GWe. further, they assume that $99.9 \%$ of the iodine is recovered at the fuel processing plant, converted to barium iodate, incorporated into cement, and, after storage for about one year, shipped to the repository. Kee et al (1976) published additional data but these latter estimates were essentially the same as those discussed above.

Measurements of the airborne radioactive effluents from a commercial nuclear fuel reprocessing plant, located in West Valley, New York, have been reported (Cocharn et al, 1970). These data indicate that the gaseous effluents from the plant contain $5-10 \%$ of the total ${ }^{129}$ I avail-. able from the dissolved fuel. However, these data may not be indicative of the true situation since it was reported that the sampling was conducted only during the dissolution process and not during the nitric acid recovery process.

On the other hand, it has been speculated that a high percentage of 
${ }^{129}$ I ( $\left.~ 90 \%\right)$ may be discharged as gaseous waste (Russell and Hahn, 1971). This estimate seems overly pessimistic, but it serves to illustrate the magnitude of the potential problem. This problem may be increased significantly with the increased reprocessing of high-burnup fuels which contain a larger activity of ${ }^{129} \mathrm{I}$.

The iodine removal system installed at the commercial nuclear fuei reprocessing plant under study consisted of a chemical scrubber followed by silver reactors. The chemical scrubber was a 20 -inch diameter by 10-foot high packed column in which the dissolver off-gases were scrubbed with a stream of mercurous and mercuric nitrate solution. The silver reactor, consisting of ceramic Berl "saddles" coated with silver nitrate, never achieved design conditions and was highly ineffective for iodine absorption (Magno et a1, 1.972).

The AGNS-Barnwell Facility located in Barnwe11, South Carolina has an extensive system for iodine cleanup. During normal operation the amount of iodine-129 input to the system is about $1 \mu \mathrm{Ci} / \mathrm{sec}$ and a decontamination factor (DF) of about 1000 is assumed. Thus, the estimated stack release rate is about $10^{-3} \mu \mathrm{Ci} / \mathrm{sec}$. Further reduction of this release rate is possible with the addition of very simple systems to condense the water vapor and trap more of the iodine before it is released (Schneider, 1977).

The iodine removal system designed for Barmwell utilizes a more efficient system than that installed in the West Valley facility which consists of traps followed by the absorption of iodine on silver zeolite (a highly efficient absorber). Finally, the iodine is absorbed on vermiculite in metal cannisters which are about $3^{\frac{1}{2}}$ feet in diameter and are nearly 8 feet high. It is assumed that the vermiculite will retain 
the ${ }^{12 y}$ I indefinitely (Schneider, 1977). Thus, these cannisters containing vermiculate represent the material for which ultimate disposal must be planned.

The ${ }^{129} \mathrm{I}$ discharged in the liquid waste, from the west Valley facility, has been estimated to be about $2 \%$ of the total present in the fuel processed each year (NFS, 1967-1970).

It now seems unlikely that, under normal operating conditions at a fuel reprocessing facility, a significant quantity of ${ }^{129} \mathrm{I}$ will be released to the environment. Before the potential for significant ${ }^{129} \mathrm{I}$ buildup in the environment was recognized it was common practice to process spent fuel which has cooled for more than 200 days without using the installed iodine cleanup system (Martin, 1973). Now that significant ${ }^{129}$ I buildup is recognized as a potential problem, iodine scrubbing systems are being redesigned for ușe in rẹprocesing factl1ties.

\section{Summary of Metabolic and Physiologic Data}

Metabolism: The size of the thyroid gland and its uptake of iodine from the blood are both very dependent upon the daily intake of stable iodine. The intakes of stable iodine vary enormously among individuals and also more generally among populations of various countries. This, in turn, is reflected in the size of the thyroid gland and perhaps in some of the other parameters of the metabolic model. The ICRP. (ICRP, 1977) has taken the fractional uptake of iodine by the thyroid to be 0.3 for the adult. The thyroid mass is assumed to be 20 grams which is an appropriate sizc for the value selected for the fractlonal uptake. Iodine is absorbed rapidly and almost completely from the gastrointestinal tract, mainly in the small intestine. In its latest report 
(ICRP, 1977), the ICRP has assumed a value of 1.0 for the fractional uptake from the gastrointestinal tract to blood.

Several models have been proposed for the metabolism of iodine (Brownel1, 1951; Riggs, 1952; Berman, 1968). The most complex of these models was that suggested by Berman which contained ten compartments, six of which were considered to represent the thyroid gland itself. Both of the models suggested by Brownell and hy Riggs are simpler and consist of essentially three compartments. Bernard (1970) analyzed Berman's model, compared it to the model of Riggs, and computed microcurie-days residence times for ${ }^{123} \mathrm{I},{ }^{124} \mathrm{I},{ }^{125} \mathrm{I},{ }^{126} \mathrm{I}$, and ${ }^{131} \mathrm{I}$. He concluded that the two models yielded essentially the same residence times. He suggested that the model of Riggs was adequate for the estimation of internal dose due to the isotopes of iodine he had studied.

The metabolic model for iodine used by the ICRP in absorbed dose and dose commitment calculations for the adult is that proposed by Riggs (1953). This model is a simple three compartment model (see figure 1). Of the iodine entering the transfer compartment a fraction, 0.3 , is assumed to be translocated to the thyroid while the remainder is assumed to go directly to excretion. Iodine in the thyroid is assumed to be retained with a biological half-life of 120 days and to be lost from the gland in the form of organic iodine. Organic iodine is assumed to be uniformly distributed among all organs and tissues of the body other than the thyroid and to be retained there with a biological half-life of 12 days. One-tenth of this organic iodine is assumed to go to fecal excretion and the rest is assumed to be returned to the transfer compartment as inorganic iodine. In the latest draft of the ICRP Conmittee 


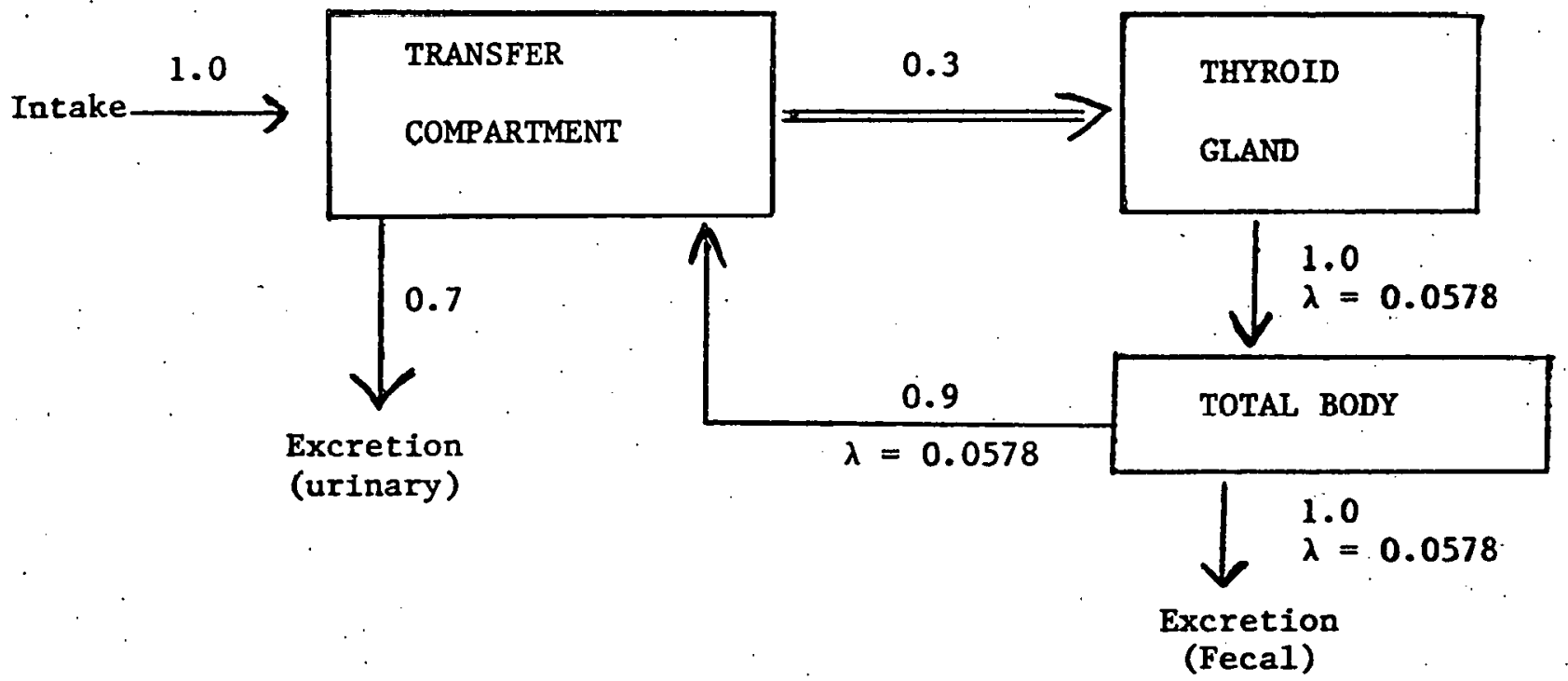

Figure 1: Schematic Diagram of Riggs' Model for Iodine Metabolism 
II material (ICRP, 1977), no mention is made of children and no guidance is given for applying the accepted model to the dosimetry of children. Figure 2, compiled by Cowser et al (1967) shows the variation of the biological half-life of iodine as a function of age. This is an important parameter which must be evaluated in the assessment of dose to large populations which consist of all ages rather than just adult radiation workers.

The Medical Research Council (1975) has publișhed some simple equations for the calculation of dose to the thyroid of a child and an adult due to the radioiodines. The six months-old child was assumed to represent the critical population group for radioiodines. The equations were used to calculate the emergency reference levels (ERL) which are used in the United Kingdom. The ERL is defined briefly as the radiation dose below which counter-measures are unlikely to be taken. No consideration was given to the release of ${ }^{129} \mathrm{I}$; possibly due to the fact that the ERL are intended for emergency situations only.

Physiologic Data: The Reference Man Report (ICRP, 1975) gives data on an iodine balance for reference man. In general, the current literature indicates that urinary excretion of iodine parallels and is approximately equal to iodine intake. The accepted values for intake are $200 \mu \mathrm{g} /$ day in foods and fluids and 0.5-35 $\mu \mathrm{g} /$ day as airborne material. Losses of iodine are $170 \mu \mathrm{g} /$ day excreted in the urine, $20 \mu \mathrm{g} /$ day in the fones, $6 \mu \mathrm{g} /$ day in sweat, and $2.3 \mu \mathrm{g} /$ day in hair. Iodine excretion is related to total body weight in adults by

$$
\text { Urinary } I(\mu g)=-45.8+(2.59 \times \omega(\mathrm{kg})) \text {. }
$$




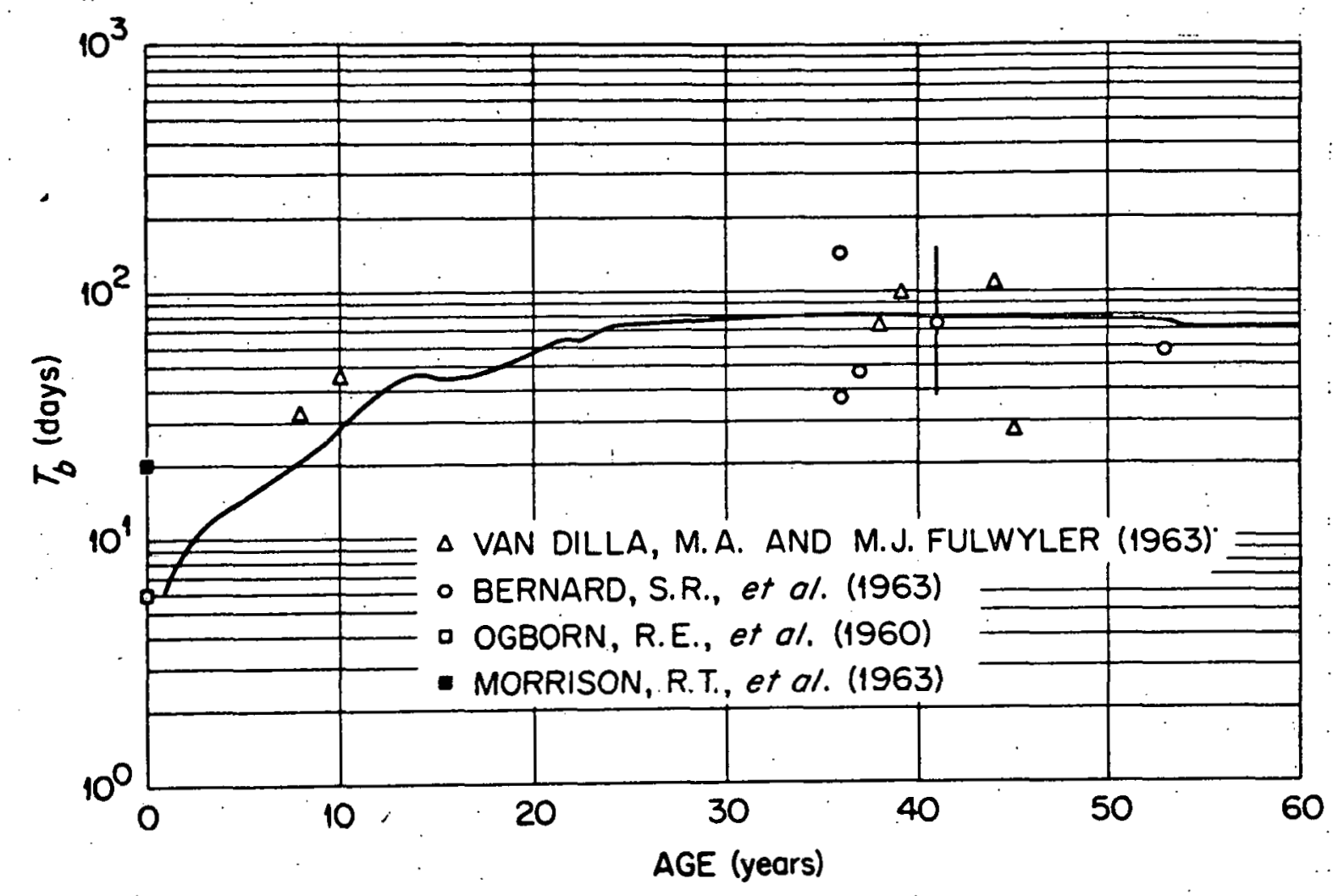

Figure 2: Variation of Biological Half-Life of Iodine as a Function of Age 
Thus, for a $70 \mathrm{~kg}$ man; I equals $135 \mu \mathrm{g} /$ day. Note also, that some data indicate that urinary excretion of iodine increases with age.

Iodine, like chlorine, is found in all body secretions. The concentration of urinary iodine in children does not differ significantly from that of adults. Infants are reported to excrete only 15-30 $\mathrm{\mu g} /$ day. The total amount of iodine in the adult thyroid is about $12 \mathrm{mg}$ (ICRP; 1975). Actually, iodine is distributed widely, yet some geographical areas are almost completely lacking in iodine. There are numerous estimates of the natural abundance of iodine ${ }^{129} \mathrm{I}$ relative to stable. ${ }^{127} \mathrm{I}$. Soldat. (1976) reports values as ranging from $10^{-12}$ to $10^{-15}$ atoms of ${ }^{129} \mathrm{I}$ per atom of ${ }^{127} \mathrm{I}$. Several factors contribute to the wide range of reported iodine intakes. The nature of the soil influences the iodine concentration in locally grown foodstuffs and water. There are also marked seasonal variations in the iodine content of plant foodstuffs and in cow's milk. An additional variable (and generally an unspecified source) is the use of iodized salt or other foods deliberately enriched with iodine.

The daily requirement of iodine is estimated to be about $150 \mu \mathrm{gm}$, but during adolescence, pregnancy, and lactation the requirement is higher. In the artifically-fed infant, iodine intake varies from 3-600 $\mu \mathrm{g} / \mathrm{day}$. In the breast-fed infant the intake of iodine is estimated to $\because$ : 25-140 $\mu \mathrm{g} / \mathrm{day}$, depending principally on the iodine concentration of human or cow's milk.

The intake of lodine in drinking water is variable according to the geologiral nature of the area. For example, the concentration in the Washington, D. C. area is 4-6.5 $\mu \mathrm{g} / \mathrm{l}$, while values from the United Kingdom 
range from $0.7-52.2 \mu \mathrm{g} / \mathrm{l}$. And, even wider variations in the iodine concentration have been reported (ICRP, 1975).

The concentration of iodine in air is reported to be $0.03 \mu \mathrm{g} / \mathrm{m}^{3}$ at zero altitude and increases with height. The maximum value recorded was $2.5 \mu \mathrm{g} / \mathrm{m}^{3}$. However, results from sampling sites near the sea have included values in the range $1-2 \mu \mathrm{g} / \mathrm{m}^{3}$. On the basis of standard inhalation and deposition rates it is estimated that reference man would have an intake of $0.0 .5 \mu \mathrm{g} /$ day of iodine in inland areas. However, for sites near the sea as much as $35 \mu \mathrm{g} /$ day of iodine may enter the body via inhalation (ICRP, 1975). Thyroid Gland: The weight of the thyroid gland is perhaps more varied than that of any other gland in the body. Its weight has been found to vary with age. (see figure 3), sex, diet, geography, climate, and external and internal stimuli, but perhaps the most important factor is iodine intake. There is strong evidence to suggest that both thyroid weight and uptake of iodine by the thyroid are correlated inversely with the daily intake of iodine (ICRP, 1975).

During prenatal life the follicles of the thyroid gland (which are the fundamental units) appear when the embryo is $24 \mathrm{~mm}$ long or about 40 days of gestational age. At 65 days, or about $5 \mathrm{~cm}$. in length, the follicles develop lumina, and at 70 days (embryo length $\sim 6 \mathrm{~cm}$ ) the colloid appears. Colloid is gelatinous and is the stored product of the secretory activity of the follicles. By age 280 days the weight of the thyroid is about 1.52 grams, however, one standard deviation of this mean is \pm 0.61 grams.

Kay, et al (1966) have derived the following relationship for the average or typical weight of the normal thyroid ( $\mu$ thyroid) from a non- 


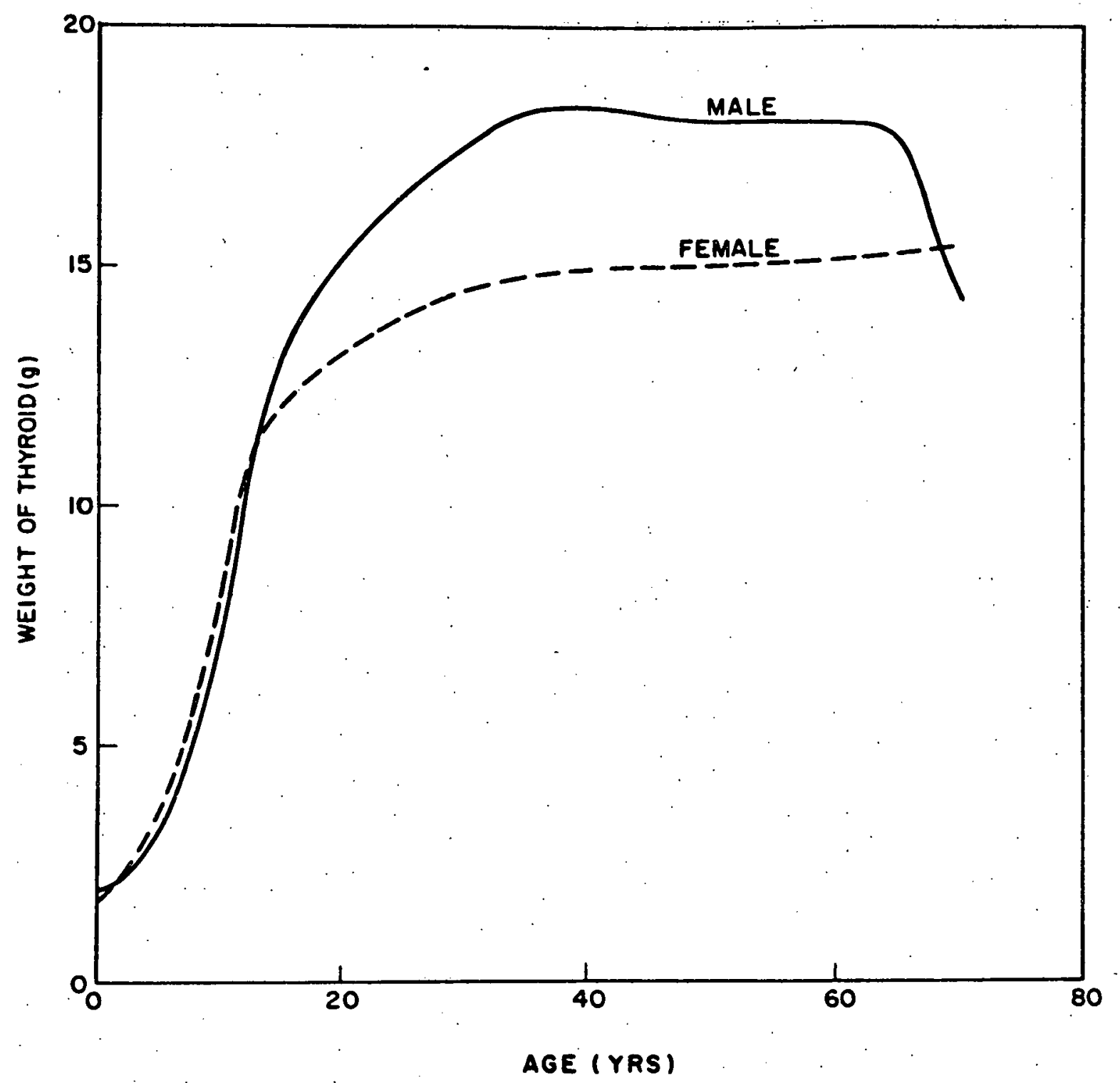

Figure 3: Weight of the Thyroid as a Function of Age 
goitrous region with age from birth to 18 years:

$$
\mathrm{T}=1.63+0.040 \mathrm{~A}+0.0001 \mathrm{~A}^{2}
$$

where $\mathrm{T}$ is the weight of the thyroid in grams and $\mathrm{A}$ is the age of the individual in months.

There are seven very definite life-cycles in the development of the thyroid gland. These are (1) thyroid enlargement of the newborn; (2) regression during infancy; (3) thyroid enlargement during prepuberty and puberty; (4) regression in postpuberty; (5) normal gland of the adult during the height of life; (6) age atrophy of the gland in the decline of life; and (7) possible rejuvenation of thyroid function in old age. In the female, another life cycle in the development of the thyroid gland is well-known. This stage is the increase in volume of the gland during pregnancy (Aschoff, 1924).

The mean thyroid weight of males (in a New York study). over 18-yearsold was found to be $17.5 \pm 6.8$ grams. The mean weight for females is $14.9 \pm 6.7$ grams. Nevertheless, the ICRP has assumed a mass of 20 grams for a reference adult male and a mass of 17 grams for the female (ICRP, 1975).

\section{Evaluations of ${ }^{129}$ I Hazards}

As stated previously, the long-lived isotope of iodine, ${ }^{129} \mathrm{I}$, has not received significant attention in terms of hazards evaluation until recently, Further, most of the papers available in the open literature have considered the release of ${ }^{129}$ I to the atmosphere from a fuel. processing facility.

Bryant (1970) calculated derived working limits (DWL) for the contin- 
uous release of ${ }^{129} \mathrm{I}$ to the atmosphere. The derived working limit is that level of radioactivity which released in a controlled fashion is considered to represent a minimum hazard. This concept is used extensively in the United Kingdom and is in many ways similar to the Radiation Protection Guides recommended by the Federal Radiation Council in this country. Bryant used two methods in her calculations; (1) the specific activity method and (2) a modified direct foliar contamination method which had been used previously for ${ }^{131} \mathrm{I}$. The latter method involved the grass-cowmilk-infant pathway which has been used extensively in the evaluation of the impact of ${ }^{131} \mathrm{I}$.

The results of this study were values of DWL for various stack heights and distances downwind from the facility. Differences between the DWL calculated by the two methods mentioned above was about a factor of 3. However, Bryant concluded that ${ }^{129} \mathrm{I}$ will not be a serious problem in the gaseous waste of a chemical plant serving a power program of up to $100,000 \mathrm{MW}(\mathrm{e})$, i.e. processing about 10 tons of fuel per day. This conclusion is in contrast with that of Magno et al (1972) who recommend the operation of the iodine cleanup system in a facility which is processing fuel regardless of the cooling time of the fuel or the throughput of the facility. This recommendation is based primarily on their measurements around the West Valley facility. However, it almost assuredly takes note of the fact that, by applying a $99 \%$ removal efficiency to the estimates of Russell and Hahn (1971), there would be $2 \times 10^{4}$ Ci of ${ }^{129} \mathrm{I}$. released by the year 2060 .

A similar calculation was reported by Hubschmann (1976) for the 
Karlsruhe Nuclear Research Center in Germany. In these calculations Hübschmann calculated an age-dependent ingestion dose factor for ${ }^{129} \mathrm{I}$ and ${ }^{131} \mathrm{I}$ (see figure 4) and also permissible iodine emission rates. He calculated that a continuous release of $1 \mathrm{pCi} /$ day of ${ }^{129} \mathrm{I}$ (at equilibrium with the various environmental parameters) leads to a dose to the infant thyroid which is 3.8 times that caused by a release of $1 \mathrm{pCi} / \mathrm{day}$ of ${ }^{13} \mathrm{I}$. For ingestion of ${ }^{129} \mathrm{I}$, the 0.5 -year-old child represented the critical population group, which is also true for all radioiodines.

This author also calculated two equivalent release rates for two particular stack heights based on an acceptable dose rate of $90 \mathrm{mrem} / \mathrm{yr}$ to the child's thyroid. However, Hübschmann's results are significantly different from those reported by Bryant in her evaluation. For example, for a 60-meter stack height, the release rates are different by a factor or more than 300 .

It is interesting to note that not all authors had ignored ${ }^{129} \mathrm{I}$. completely. Cowser, et al (1967) compiled a list of more than 100 radioisotopes produced in nuclear explosions: This study was intended to evaluate the impact of a sea-level canal across Panama constructed with nuclear explosives. These authors calculated that the dose to the thyroid gland over 7.0 years following the ingestion of a soluble form of ${ }^{129} \mathrm{I}$ would be $13.5 \mathrm{rem} / \mu \mathrm{Ci}$. In a ranking of importance according only to the dose delivered, ${ }^{129} \mathrm{I}$ was listed second with only ${ }^{90} \mathrm{Sr}$ delivering more dose to the critical organ. The dose from ${ }^{129} \mathrm{I}$. was an order of magnitude higher than that from ${ }^{239} \mathrm{Pu}$ and four orders of magnitude higher than that from ${ }^{137} \mathrm{Cs}$. 


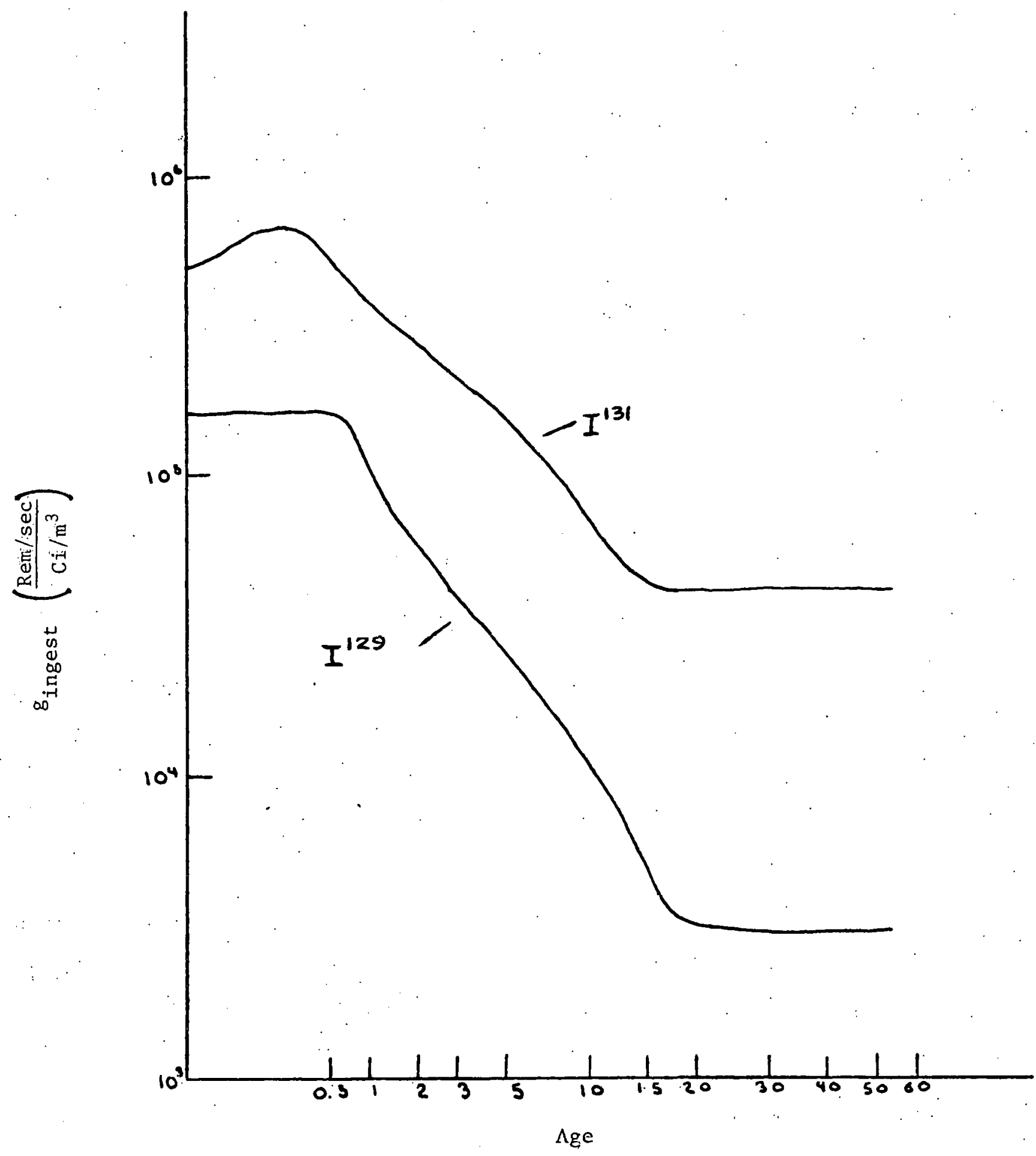

Figure 4: Age-Dependent Ingestion Dose Factor, $g_{\text {ingest }}$ (after Hiibschmann, 1976) 
Probably one of the most comprehensive papers on the impact of ${ }^{129} \mathrm{I}$ on the environment was the work of Soldat (1976). In this paper the author compiled the biological and metabolic parameters necessary to calculate the dose due to ${ }^{129} \mathrm{I}$ to humans of several ages. The ages considered in the study were ages $1,4,14$ and adult.

Soldat reported complete details on the ecological parameters (e.g. deposition velocity, soll uptake, ecological half-life, etc.) necessary for the calculations. A summary of the selected parameters is given in Table I. Table.II lists some of the available data on the aquatic bioaccumulation factors for iodine, while Table III summarizes the parameters as a function of age which should be used in calculating the thyroid dose factors for ${ }^{129} \mathrm{I}$. The resulting thyroid dose factors for ${ }^{129} \mathrm{I}$ are shown in Table IV. These data include the dose per unit intake by inhalation and ingestion for the four age groups mentioned previously. The thyroid dose per unit concentration of ${ }^{129} \mathrm{I}$ in a1r are given in Table V: This table considers four exposure pathways for each of the four ages. With the exception of the milk consumption pathway, the adult receives the highest thyroid dose in all cases.

Soldat's paper has been criticized by Thompson (1976) who stated that the food consumption data utilized in the calculations were extreme and resulted in significantly elevated dose estimates for ${ }^{129} \mathrm{I}$ in the thyroid. Thompson utilized data supplied by the U:S. Department of Agriculture and recalculated the thyroid dose estimates. The data are compared to those of Soldat in Table VI. Soldat replied to the criticisms of Thompson by indicating that his calculations were for a hypo- 
Table I . Estimated Ecologlcal Parameters for Iodine*

Deposition velocity from air to ground (m/sec). . . . . $10^{-2}$

Fraction of aerial deposition retained on plant . . . . . 0.25

"Ecological" half-life on plant (days). . . . . . . . . 14

Fraction of deposited iodine translocated to part of plant eaten - leafy vegetables. . . . . . . . . 1.0 other vegetables and grain. . . . . . . . . . . . . 0.1

Soil uptake (pCi/kg plant (wet) per pCi/kg soil (dry)) . . . 0.02

Transfer from feed to milk (day/liter) - cow. . . : . . . 0.01

- goat........ 0.2

Transfer from feed to meat (day/kg) - beef . . . . . . 0.02

- pork . . . . . . 0.09

- chicken. . . . . 0.004

Transfer from feed to chicken eggs (day/egg). . . . . . . 0.08

* After Soldat, 1976. 
Table II. Aquatic Bioaccumulation Factors for Iodine:

\begin{tabular}{|c|c|c|c|c|}
\hline \multirow[t]{2}{*}{ Organism } & Fresh Water & \multicolumn{3}{|c|}{ Salt Water } \\
\hline & (Thompson, et al. 1972) & (Thompson, et & 1972) & (Freke, 1967) \\
\hline Fish & 15 & 10 & & 20 \\
\hline Invertebrates & 5 & 50 & & 100 \\
\hline Algae & 40 & $4000^{*}$ & & 10,000 \\
\hline
\end{tabular}

These authors also reported a measured value of 1000 . 
Table III. Parameters Used in Calculating Thyroid Dose Factors for ${ }^{129} I *$

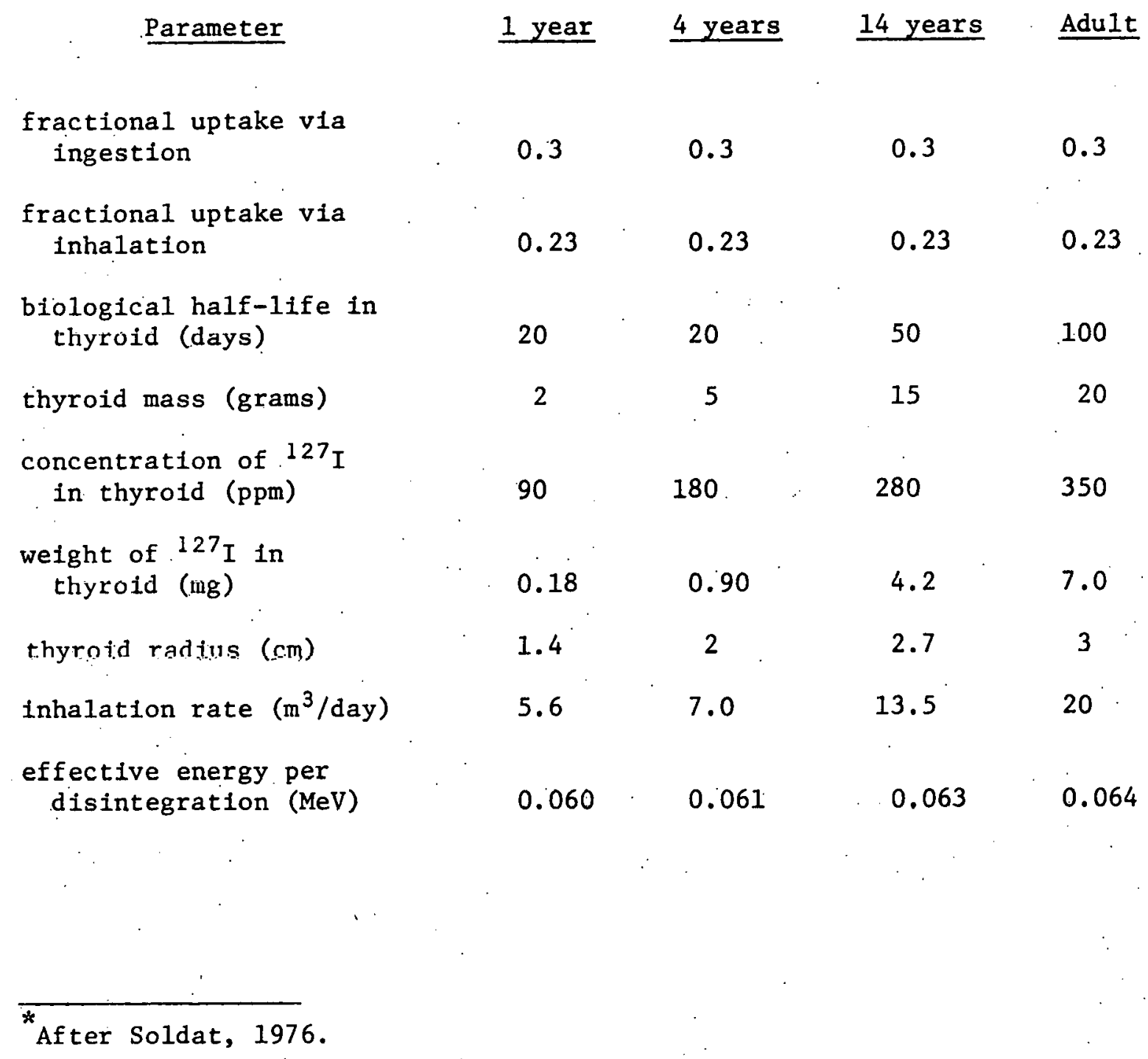


Table IV. Thyroid Dose Factors for ${ }^{129} \mathrm{I}^{*}$

Dose per Unit Intake

mrem/pCi ingested

mrem/pCi inhaled.

\section{Equilibrium Dose Rate}

mrem/yr per pCi maintained in the thyroid

\section{Thyroid Content of 129 I to Yield}

\section{$1.5 \mathrm{rem} /$ year}

$\mathrm{pC} \dot{\mathrm{i}}$

${ }^{129} \mathrm{I}: \quad 127 \mathrm{I}$

pCi ${ }^{129} \mathrm{I} / \mu \mathrm{g} \mathrm{I}$

pCi ${ }^{129} \mathrm{I} / \mathrm{g}$ thyroid

$\overline{\text { *after Soldat, } 1976}$

\begin{tabular}{llll}
1 year & 4 year & \multicolumn{1}{l}{14 year } & Adult \\
$1.33(-2)$ & $5.45(-3)$ & $4.67(-3)$ & $7.05(-3)$ \\
$1.02(-2)$ & $4.18(-3)$ & $3.58(-3)$ & $5.40(-3)$ \\
& & & \\
& & & \\
$5.59(-1)$ & $2.30(-1)$ & $7.87(-2)$ & $5.94(-2)$ \\
& & & \\
& & & \\
$2.68(3)$ & $6.52(3)$ & $1.91(4)$ & $2.53(4)$ \\
$9.26(-2)$ & $4.31(-2)$ & $2.66(-2)$ & $2.10(-2)$ \\
$1.49(1)$ & $7.25(0)$ & $4.54(0)$ & $3.61(0)$ \\
$1.34(3)$ & $1.39(3)$ & $1.27(3)$ & $1.26(3)$
\end{tabular}


Table V. Thyroid Doses from Unit Concentration of ${ }^{129}$ I in Air*

$\mathrm{mrem} / \mathrm{yr}$ per $\mathrm{pCi} / \mathrm{m}^{3}$

Exposure Pathway

inhalation

milk consumption

leafy vegetable consumption

beef consumption
1 year 4 years 14 years Adult

$\begin{array}{rrrr}21 & 11 & 18 & 39 \\ 5800 & 2400 & 2000 & 3100 \\ 0 & 510 & 730 & 1500 \\ 0 & 320 & 500 & 1300\end{array}$

*After Soldat, 1976 
Table VI. Thyroid Doses from Unit Concentration of ${ }^{129}$ I In Air*

Exposure Pathway Age Categories

1 (mrem/yr per $\mathrm{pCi} / \mathrm{m}^{3}$ )

Inhalation

21

11

18

39

Milk consumption:

Soldat

Thompson

2934

2400

1241

2000

896

3100

Leafy vegetable consumption:

Soldat

Thompson

0

510

730

217

1500

40

100

412

Beef Consumption:

Soldat

0

320

57

229

500

484

1300

Thompson

.

* After Thompson, 1976 
thetical "maximum individual." However, it is interesting to note that for leafy vegetable and beef consumption in the one-year-old, Thompson obtains a much higher dose estimate. With this exception, the data of Thompson give lower dose rates than those of Soldat.

In a recent appraisal of thyroid burdens of ${ }^{12 y} \mathrm{I}$ from various dietary sources, Book and his colleagues (1977) have evaluated the impact on the same four age groups as Soldat: The two most important sets of data from this study are shown in Tables VII and VIII. Average dietary intake of major food items are given Table VII assuming a continuous ${ }^{129}$ I concentration in air of $1 \mathrm{pCi} / \mathrm{m}^{3}$. Table VIII summarizes the data on daily intake, thyroidal burden, and dose rate for ${ }^{129}$ I from common dietary sources. These data are, in most cases, slightly lower than those reported previously by Soldat (1976). However, in a manner similar to Thompson's analysis the dose rate for the one-year-old is higher than that estimated by Soldat. In fact, for leafy vegetable consumption, Soldat estimates a dose rate of zero for the one-year-old while the estimate of Book et al is $1.1 \mathrm{rem} / \mathrm{y}$ !

A recent paper by deMarsily and his colleagues. (1977) has considered the confining ability of geologic formations for the three major radionuclides which have half-lives of the order of magnitude of geologic times. These are lodine-129, neptunium-237, and plutonium-239. These authors reminded us of the point made earlier in this manuscript. That is, iudine-129 is generally considered to be present in the spent fuel or in the liquid waste, but not in the solidified waste. However, since ${ }^{129}$ I release to the atmosphere is undesirable because of the potential for 
Table VII. Average Dietary Intake of Major Food Items by Representative Age Groups*

\begin{tabular}{lccccc} 
& \multicolumn{5}{c}{ Daily Food Intake (gm) } \\
$\begin{array}{l}\text { Item } \\
\text { Milk. and Milk } \\
\text { products }\end{array}$ & 1250 & 650 & 570 & 690 & 400 \\
Meat & 1600 & 100 & 130 & 240 & 340 \\
Leafy vegetables & 2900 & 80 & 80 & 100 & 110 \\
$\begin{array}{l}\text { Cereals } \\
\begin{array}{l}\text { Other vegetables and } \\
\text { fruit }\end{array}\end{array}$ & 540 & 60 & 80 & 130 & 120 \\
\hline
\end{tabular}

* After Book et a1 (1977) 
Table VIII. Daily ${ }^{129}$ I Intake, Thyroid Burden; and Radiation Dose Rate to Thyrolds of 1-, 4-, and 14-year-olds, and Adults from Ingestion of Foods Produced at Locations with 129 I Concentrations Equal to 1 PCi/m ${ }^{3}$ Air*

\begin{tabular}{|c|c|c|c|c|c|c|c|c|c|c|c|c|}
\hline & & $\begin{array}{c}\text { Daily } \\
\text {. }\end{array}$ & $\begin{array}{l}{ }^{29} \mathrm{I} \text {. In } \\
\left.{ }_{\mathrm{nCi}}\right)\end{array}$ & & & oidal & $\begin{array}{l}{ }^{29} \mathrm{I} \\
(\mathrm{nCI})\end{array}$ & den & & roid & $\begin{array}{l}\text { Dos } \\
\text { a/yr) }\end{array}$ & Rate \\
\hline$\cdot$ & 1 & 4 & 14 & Adu1t & 1 & 4 & 14 & Adult & 1 & 4 & 14 & Adult \\
\hline Milk Products & 0.81 & 0.71 & 0.86 & 0.50 & 7.0 & 6.1 & 18.6 & 21.6 & 4.0 & 1.4 & 1.5 & 1.3 \\
\hline Meat & 0.16 & 0.21 & 0.39 & 0.54 & 1.4 & 1.8 & 8.4 & 23.4 & 0.8 & 0.4 & 0.7 & 1.4 \\
\hline Leafy Vegetables & 0.23 & 0.23 & 0.29 & 0.32 & 2.0 & 2.0 & 6.3 & 13.8 & 1.1 & 0.5 & 0.5 & 0.8 \\
\hline Cereals & 0.04 & 0.04 & 0.07 & 0.07 & 0.3 & 0.3 & 1.5 & 3.0 & 0.2 & 0.1 & 0.1 & 0.2 \\
\hline $\begin{array}{l}\text { Other vegetables } \\
\text { and fruits }\end{array}$ & 0.05 & 0.06 & 0.09 & 0.10 & 0.4 & 0.5 & 1.9 & 4.3 & 0.2 & 0.1 & 0.1 & 0.3 \\
\hline Total & 1.28 & 1.25 & 1.70 & 1.53 & 11.1 & 10.7 & 36.7 & 66.1 & 6.3 & 2.5 & 2.9 & 4.0 \\
\hline
\end{tabular}

* After Book et al. (1977). 
long-term buildup in the environment, it must be trapped in some sort of filter and disposed of in some manner.

In this study, the chief mechanism of migration of ${ }^{129} \mathrm{I}$, and the other radionuclides considered, was the movement of groundwater. Such a scenario is considered highly unlikely since the geologic formations selected for a repository have not been subject to water intrusion over. periods measured in geologic time. However, most authors assume water intrusion into a geologic waste repository to provide a mechanism for radionuclide migration. Thus, although perhaps an unacceptable scenario, it is informative to consider in more detail the studies of deMarsily and his colleagues. The authors selected five geologic formations of different characteristics for this study. These characteristics are listed in Table IX. Formation 1 has very poor confining properties while formation 5 is a highly confining layer and is almost completely impervious. In all five cases, the formations were assumed to be 500 . meters thick in order to make comparisons possible.

From these calculations a series of "break-through" curves were obtained. These curves give the ratio of the concentration (or activity) of effiuents reaching the environment to the concentration (or activity) leaving the repository, as a function of time. The data for ${ }^{129} \mathrm{I}$ are presented in Table $X$. Two parameters which characterize the role of the formation are given in the tabulation. These are the transmission rate of the formation and the duration of transfer.

The first parameter is the ratio of the cumulated activity injected 
Table IX. Parameters of the Geologic Formations*

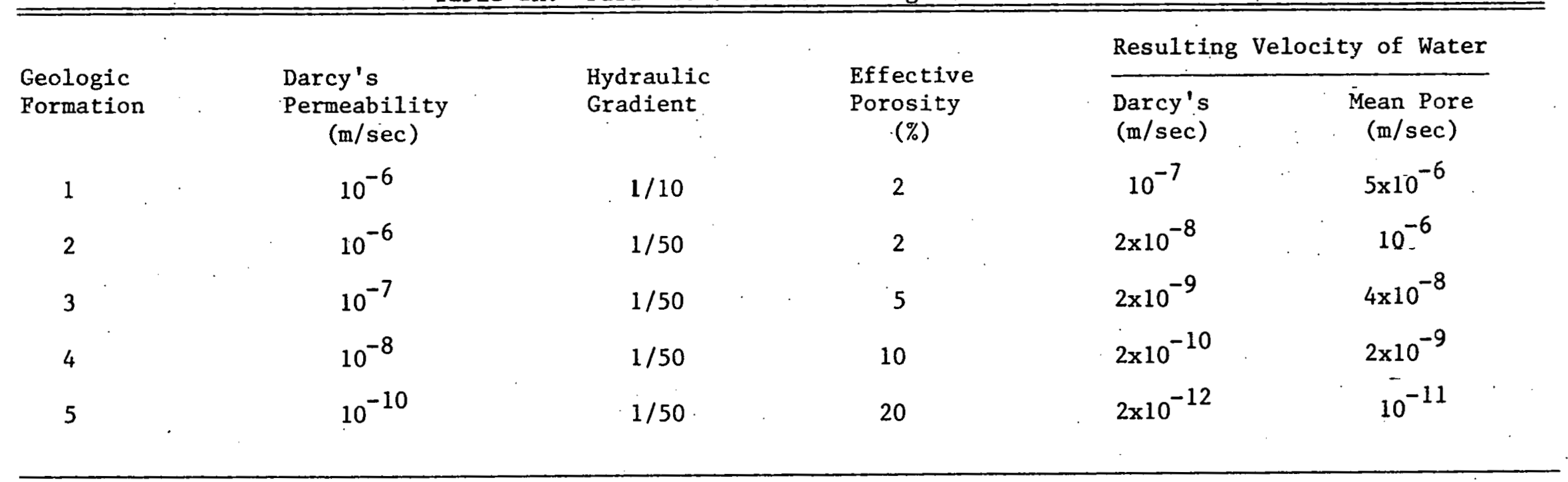


Table X: Step Function Response for ${ }^{129} \mathrm{I}$ in Several Geologic Formations*

$\begin{array}{cccr}\begin{array}{c}\text { Geologic } \\ \text { Formation } \\ \text { Type }\end{array} & \begin{array}{c}\text { Mean Pore } \\ \text { Water } \\ \text { Velocity } \\ (\mathrm{m} / \mathrm{sec})\end{array} & \begin{array}{c}\text { Transmission } \\ \text { Rate of the } \\ \text { Formation } \\ (\%)\end{array} & \begin{array}{r}\text { Duration } \\ \text { of } \\ \text { Transfer } \\ \text { (years) }\end{array} \\ 1 & 5 \times 10^{-6} & 100 & 6 \\ 2 & 10^{-6} & 100 & 29 \\ 3 & 4 \times 10^{-8} & 100 & 725 \\ 4 & 2 \times 10^{-9} & 99 & 14,500 \\ 5 & 10^{-11} & 93 & 2,840,000\end{array}$

* After deMarsily et al (1977) 
into the environment versus the radioactivity leaving the repository. Radioactive decay during the transfer time is taken into account. The parameter is a measure of the effectiveness of retention of the formation.

The duration of transfer is the amount of time needed for the step. function response to reach a maximum value. Thus, this parameter is a measure of the delay introduced by the formation in the return of the waste to the environment.

For lodine-129, using the deMarsily scenario, the data indicate that even for a confining formation (such as case 4) nearly 100 percent will return to the environment. The delay is less than 15,000 years and contamination will begin at about 4000 years after the waste starts leaking. Even for an extreme geological formation (case 5), about $93 \%$ of the ${ }^{129}$ I will be transmitted with a delay of less than 3 million years.

Tó investigate the effects of containing the waste in a material such as borosilicate glass before placement in the repository the authors postulated two hypotheses and used these as input functions for a further study of the five geologic formations. The two hypotheses are:

Case 1 - The structure of the borosilicate glass is never damaged and the release of lodine-129 occurs only by diffusion through the glass at a rate of $10^{-16} \mathrm{~m}^{2} / \mathrm{sec}$. Case 2 - At 10,000 years after burial, the glass matrix structure is damaged, and the total load of iodine-129 is released into the leaching water at a constant rate within 5000 years. 
The results of their analysis are summarized in Table XI. These results are from simplified calculations which were based on the assumption that transport by water begins immediately after storage. In the table, the data are given in terms of the concentration of the element in water flowing over the repository, when it reaches the environment, divided by the maximum permissible concentration in drinking water.

There is an apparent paradox shown in these data. That is, the more confining the geologic formation the more concentrated will be the radionuclides in the water reaching the environment. This finding indicates that the greater volume of water flowing through the repository the less toxic it will be when it reaches the environment. However, the results of the study are more easily understood when it is considered that, according to the assumptions, the ${ }^{129} \mathrm{I}$ is entering the leach water at a constant rate. The radioactivity is reaching the biosphere at a constant rate, Independent of the flow and volume of the leach water. Thus, the concentration of $129 \mathrm{I}$ in the leach water is inversely proportional to the volume of water transporting the radionuclide. Nevertheless, from this analysis the authors conclude that, if the integrity of the glass matrix can be guaranteed for an indefinite period, the choice of the geologic formation in which the waste are to be confined is simplified. Several authors have considered the effect of partitioning the waste before placing it in a geologic repository. One of the radionuclides considered for partitioning (or removal) was the long-lived ${ }^{129} \mathrm{I}$. Cohen (1976) concluded, in his evaluation of cost vs risk for partitioning, that on the basis of risk alone, partitioning was not justified. He saw 
Table XI. Concentration of Iodine-129 in the Water Reaching the Human.Environment Expressed as Ratios to the Maximum

Permissible Concentrations in Drinking Water*

\begin{tabular}{|c|c|c|c|c|c|}
\hline \multirow[b]{2}{*}{$\begin{array}{l}\text { Geologic } \\
\text { Formation }\end{array}$} & \multirow[b]{2}{*}{$\begin{array}{c}\text { Transmission } \\
\text { Rate of the } \\
\text { Formation } \\
(\%)\end{array}$} & \multicolumn{2}{|c|}{ Case 1} & \multicolumn{2}{|c|}{ Case 2} \\
\hline & & $\begin{array}{l}\text { Ratio to } \\
\text { MPC }_{w}\end{array}$ & $\begin{array}{l}\text { Time when } \\
\text { maximum } \\
\text { is observed } \\
\quad \text { (years) }\end{array}$ & $\begin{array}{l}\text { Ratio to } \\
\mathrm{MPC}_{\mathrm{w}}\end{array}$ & $\begin{array}{l}\text { Time when } \\
\text { maximum } \\
\text { is observed } \\
\quad \text { (years) }\end{array}$ \\
\hline 1 & 100 & $1.4 \times 10^{-2}$ & 5 & 0.58 & 10,000 \\
\hline 2 & 100 & $7 \times 10^{-2}$ & 25 & 2.9 & 10,000 \\
\hline 3 & 100 & 0.7 & 600 & 28.0 & 10,700 \\
\hline 4 & 99 & 5.1 & 10,000 & 250.0 & 20,000 \\
\hline 5 & 93 & 5.3 & $1.7 \times 10^{6}$ & 170.0 & $1.45 \times 10^{6}$ \\
\hline
\end{tabular}

* After deMarsily et al (19:77) 
partitioning as a further reduction of an already minor (post-1000 year) problem. This short paper did not present a breakdown of the individual radionuclides present in the waste and considered only actinidedepleted, light-water-reactor waste. The relative toxicity index concept was used to compare the relative hazard of this waste to the hazard from $0.2 \%$ uranium ore.

In a follow-on study, Tonnessen and Cohen (1977) investigated the naturally occurring hazardous materials in deep geologic formation in an attempt to place the burial of wastes in the proper perspective. These authors concluded their results indicated that, over time, nuclear waste toxicity decreases to. levels below those of naturally occurring hazardous materials. Again, no detailed listing of the radionuclides is given which would identify the presence or absence of ${ }^{129} \mathrm{I}$ in this evaluation.

Burkholder et al (1975) investigated the incentives for separating and eliminating various radionuclides (in particular the transuranics) from radioactive waste prior to final geologic storage. In this situation the waste was assumed to be located in a non-salt particulate geologic medium and release is via the leach incident-transport pathway. Exposure pathways to man were defined and the effects of changing transport parameters on the potential dose to a "maximum" individual were calculated. Transport parameters studied were leach rate, path length and time of initial release from the repository after the year 2000. Results of the study indicated that, for reasonable storage conditions, the potential incremental radiation dose would be approximately equivalent to the dose 
due to the natural radiation background. They concluded that the Incentives for.a special effort to remove any radionuclides from highlevel waste were extremely small. However, the study demonstrated that there may be incentives for converting high-level calcine into glass.

Additional information on this research can be found in Burkholder et ai (197.6) and Bartlett et al (1976).

\section{Summary and Conclusions}

A major portion of the information used to evaluate the impact of ${ }^{129} \mathrm{I}$ on man and his environment has been obtained from our extensive knowledge of ${ }^{131} \mathrm{I}$. Only recently (within less than 10 years) has the interest shifted to this long-lived radionuclide.

Some of the evaluations presented to date indicate that ${ }^{129} \mathrm{I}$ released to the environment from fuel reprocessing plants may, under certain conditions, have the potential for delivering significant doses to the thyrold glands of selected population groups. For example, Soldat (1976) estimated that in the one-year old the thyrold dose would approach $6 \mathrm{rem} /$ year for a concentration in air of $1 \mathrm{pCi} / \mathrm{m}^{3}$.

For isolation of radioactive waste in deep geologic formations, 1 is expected that licensing procedures will require an evaluation of the unlikely event of a breach in containment of the formation. One such scenario assumes a breach of the formation at the repository site, Intrusion by ground water, transport by migration of the radiolodine to the biosphere, and its subsequent uptake by man through a foodchain pathway. Thus, the primary pathways are ingestion through drinking 
water or foodstuffs containing the released radionuclides. There are 1ittle data available at this time with which to evaluate the impact of ${ }^{129} \mathrm{I}$ and the ingestion pathway. Additional environmental and exchange data on lodine would be useful to more accurately quantify this impact. In particular, the evaluation of ${ }^{129} \mathrm{I}$ ingestion in various age groups is needed.

It is highly likely that much of the necessary input data are available In a complete compllation in the scientific literature. Thus, the Initial step toward providing a better evaluation of the impact of ${ }^{129} \mathrm{I}$ would be to search for and collect these data. Many computer codes are available to calculate the dose to any particular population group once the necessary Input data are obtained. For example, the data summarized in Table XII are for the ICRP Reference Man and use the standard ICRP metabolic model discussed earlier. As can be seen from the table, the dose equivalent per unit intake is calculated for three different inhalation classes and for ingestion. However, these data are for an adult man, for which the pertinent parameters have been compiled. No complete compilation of similar information is available for children, the critfcal population group.

There are a number of questions which must be answered in such an evaluation. In general, these deal with changes in metabolism of the radionuclide when it becomes incorporated into foodstuffs. For example, does the amount transferred across the gastrointestional wall barrier change due to the manner in which the radionuclide is bound? In the case of lodine this appears to be unlikely, but this behavior has been noted 
Table XII. Dose Equivalent per Unit Intake of ${ }^{129} \mathrm{I}$ - Reference Man

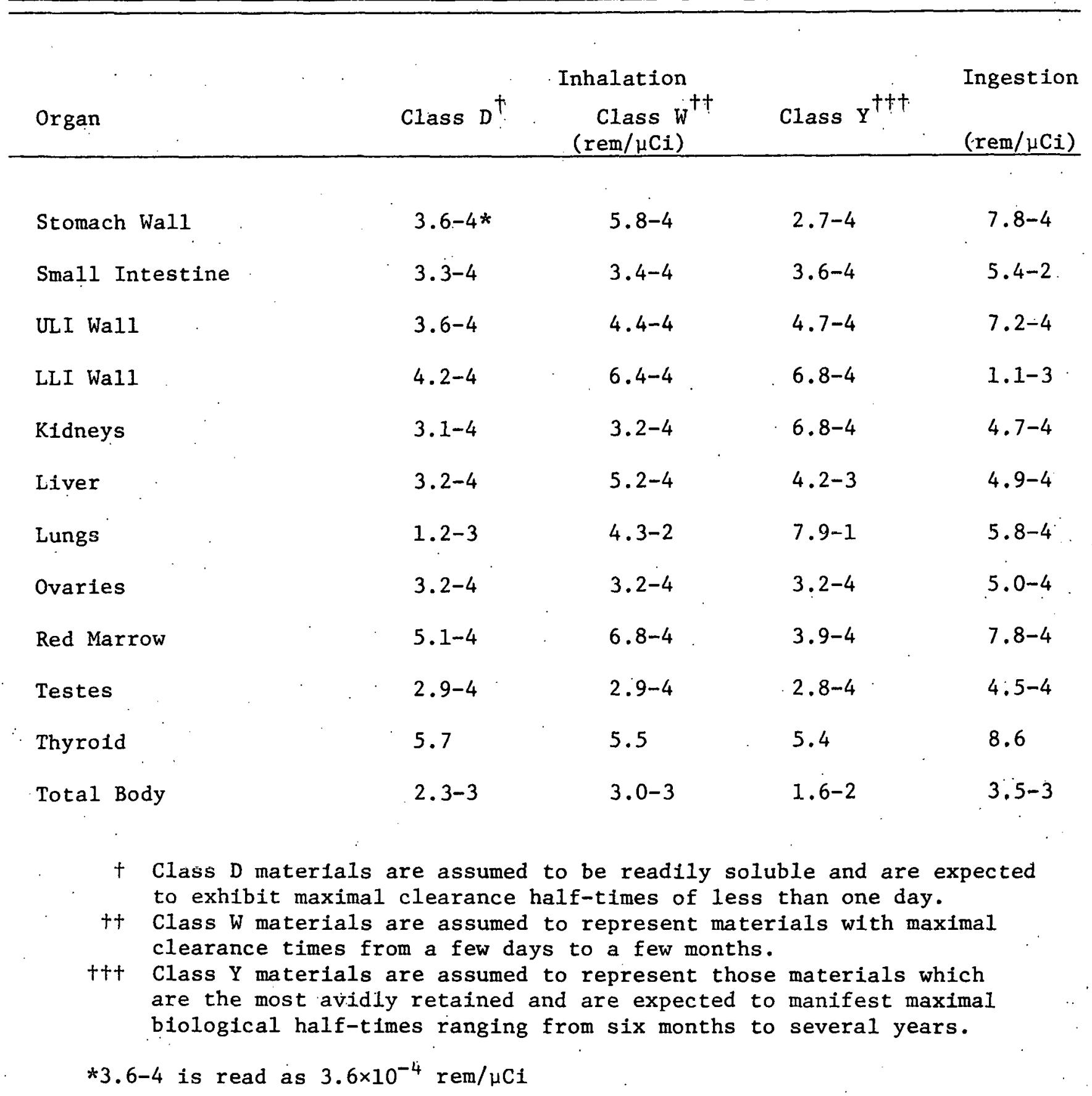


for other elements. One of the most well-known of these is niobium. When niobium is ingested in elemental form only about $1 \%$ of the material will cross the gastrointestinal barrier into the blood. However, if the niobium is incorporated in foodstuffs, $60 \%$ of the material will cross the gastrointestinal wall.

Nevertheless, in order to perform a complete evaluation of the impact of ${ }^{129} \mathrm{I}$ on man and his environment, behaviors typical of that above must be investigated so that models can represent accurately the metabolism of the radioactive elements of interest.

\section{Acknowledgements}

The author would like to thank M. R. Ford and S. B. Watson of the Oak Ridge National Laboratory for their assistance in obtaining dose estimates for Reference Man utilizing the most up-to-date techniques. The valuable comments of R. L. Shoup, W. A. Goldsmith, and G. H. Jenks of the Office of Waste Isolation are gratefully acknowleged. Thanks also to Mrs. R. Salley for the careful preparation of the several drafts of this manuscript. 


\section{References}

Aschoff, L., Chapter XIII, "The Goiter Problem, Especially the Goiter of Puberty," Letters on Pathology, pp. 313-319, Paul B. Hoeber, New York (1924)

Bartlett, J. W., H. C. Burkholder, and E. J. Wheelwright, "The Incentives and Technology for Partitioning," International Symposium Management of Wastes from the LWR Fuel Cycle, Colorado, CONF-76-0701 (1976)

Baverstock, K. F. and J. Vennart, "Emergency Reference Levels for Reactor Accidents: A Re-examination of the Windscale Reactor Accident," Health Physics Journal, 30, 339-344 (1976)

Berman, J., J. Clin. Endocrino1. Metab., 28, 1 (1968)

Bernard, S. R., "Applications of Berman's Ten-Compartment Model for Human Iodine Metabolism to Estimation of Microcurie-Days Residence of $123 \mathrm{I}$, ${ }^{124} \mathrm{I}, 125 \mathrm{I},{ }^{126} \mathrm{I}$, and ${ }^{131} \mathrm{I}, "$ Health Phys. Div. Ann. Prog. Rpt., ORNL4584 (October 1970)

Blomeke, J. O. and C. W. Kee, "Projections of Radioactive Wastes from the Nuclear Fuel Cycle," Proc. of Eighth Midyear Topical Symp. of the Health Physics Society, CONF-741018 (October 1974)

Blomeke, J. O. and C. W. Kee, "Projections of Wastes to be Generated,". International Symposium Management of Wastes from the LWR Fuel Cycle, Denver, Colorado, CONF-76-0701 (1976)

Book et al, "Thyroidal Burdens of ${ }^{129}$ I from Various Dietary Sources," Health Physics Journal, 32, 143-148 (1977)

Boulos et al, "Iodine-129 in Thyroid Glands," Health Physics Journal, $\underline{24}, 375-378$ (1973)

Browne11, G. L., J. C1in. Endocrino1. Metab., 11, 1095 (1951)

Bryant, P. M., "Derivation of Working Limits for Continuous Release Rates of Iodine-131 to Atmosphere in a M1lk-Producing Area," Health Physics Journal, 10, 249-257 (1964)

Bryant, P. M., "Derivation of Working Limits for Continuous Release Rates of ${ }^{129}$ I to Atmosphere," Health Physics Journal, 19, 611-616 (1970)

Rurkholder, H. C.; M. O. Cloninger, D. A. Baker, and G. Janscn, "Incentives for Partitioning High Level Waste," BNWL-1927, (November 1975) 
Burkholder, H. C. et al, "Incentives for Partitioning of High-Level Waste," BNWL-SA-5633 in Nuclear Engineering (November 1976)

Cochran,. J. A. et al, "An Investigation of Airborne Radioactive Effluents from an Operating Nuclear Fuel Reprocessing Plant," BRH/NERHL 70-3 (1970)

Cohen, J. J., "Why Partition Nuclear Waste?", UCRL-78274 Rev. 1 (June 11, 1976)

Cowser, K. E., S. V. Kaye, P. S. Rohwer, W. S. Snyder, and E. G. Struxness, "Dose-Estimation Studies Related to Proposed Construction of an Atlantic-Pacific Interoceanic Canal with Nuclear Explosives: Phase I," ORNL-4101 (March 1967)

Gabay, J. J. et al, "A Method for Determining Iodine-129 in Milk and Water," Hea1th Physics Journal, 26, 89-96 (1974)

Hübschmann, W. G., "Estimating Permissible ${ }^{129}$ I-Emission Rates," Health Physics Journal, 30, 496-498 (1976)

ICRP Report No. 23, Report of the Task Group on Reference Man, Pergamon Press (1975)

ICRP Committee 2 Draft Report, "Limits for Intakes of Radionuclides by Workers," unpublished (1977).

Kay, Chester, Simon Abrahams, and Philip McClain, "The Weight of Normal Thyroid Glands, in Children," Arch. Pathol., 82, 349-352 (1966)

Kee, C. W., A. G. Croff, and J. O. Blomeke, "Updated Projections of Radioactive Wastes to be Generated by the U.S. Nuclear Power Industry," ORNL/TM-5427 (December 1976)

Magno, P. J., T. C. Reavey, and J. C. Apidianakis, "Iodine-129 in the Environment Around a Nuclear Fuel Reprocessing Plant," ORP/SID 72-5 (November 1972)

deMarsily, G. et al, "Nuclear Waste Disposal: Can the Geologist Guarantee Isolation," Science, 197, (4303) 519-527 (August 5, 1977)

Martin, James A., Jr., "Calculations of Environmental Radiation Exposures and Population Doses Due to Effluents from a Nuclear Fuel Reprocessing. Plant," Rad. Data Rpts. XIV (2) 59-76 (February 1973)

Medical Research Council, "Criteria for Controlling Radiation Doses to the Public After Accidental Escape of Radioactive Material," Panel on Emergency Reference Levels, Medical Research Council, London (1975) 
Morley, F, and Pamela M. Bryant, "Radiation Exposures to Man from Releases of Radioactive Effluents," International Symposium Management of Wastes from the LWR Fuel Cycle, Denver, Colorado, CONF-760701 (1976)

Nuclear Fuel Services, Inc. West Valley Reprocessing Plant, NFS Quarterly Reports (1967-1970)

Porz, F., Nuclear Kesearch Center Karlsruhe, Rept. Nr. 1912 (1974)

Riggs, D. S., "Quantitative Aspects of Iodine Metabolism in Man," Pharmacol. Rev. 4, 285 (1953)

Russell, J. L. and P. B. Hahn, "Public Health Aspects of I-129 from the Nuclear Power Industry," Radiol. Health Data Rpts., 12 (4) 189-194 (1971)

Schneider, A., personal communication (1977)

Soldat, J. K., "Radiation Doses from Iodine-129 in the Environment," Health Physics Journal, 30, 61-70 (1976)

Thompson, J. D., Jr.; "Comments on the Paper, 'Radiation Doses from Iodine-129 in the Environment,' by. J. K. Soldat," Health Physics Journal, $31,287-288$ (19.76)

Tonnessen, K. A. and J. J. Cohen, "Survey of Naturally Occurring Hazardous Materials in Deep Geologic Formations." A Perspective on the Relative Hazard of Deep Burial of Nuclear Wastes," UCRL-52199 (January 14, 1977) 